\title{
Validating and Utilizing an Outcomes-Based Education (OBE) Student Teaching Manual in a State University in the Philippines
}

\author{
Josephine C. Marasigan* \\ Eastern Samar State University, Philippines
}

Article Type: Article

Article Citation: Josephine C Marasigan. Validating and utilizing an Outcomes-Based Education (OBE) student teaching manual in a State University in the Philippines. Indian Journal of Science and Technology. 2020; 13(07),743-755.D0l:10.17485/ijst/2020/ v013i07/148722

Received date: November 7, 2019

Accepted date: January 12, 2020

*Author for correspondence:

Josephine C. Marasigan

jos002200@yahoo.com P Eastern

Samar State University, Philippines

\begin{abstract}
Objectives: To study research design assessing and describing the content validity and utilization of the Outcomes-Based Education (OBE) Student Teaching Manual. Methods: This study used a descriptive-evaluation research design assessing and describing the content validity and utilization of the Outcomes-Based Education (OBE) Student Teaching Manual using "ADDIE" Instructional Design Model. Findings: Results revealed that there was a relatively high and strong agreement among the three groups of respondents that the content of the OBE-Student Teaching Manual in all the five parts is valid, a high level of agreement by the respondents that the OBE-Student Teaching Manual was fully utilized in the four (4) phases of the student teaching program. A strong indication that ratings among the three groups of respondents on the content validation in the five parts of the OBE-Student Teaching Manual are not significantly different, a notable revelation that there were no significant differences on the ratings by the stakeholders on the Utilization of the OBE-Student Teaching Manual. Recommendation/ Novelty: The content of this manual is valid and considered to be fully utilized. It is highly recommended to be used by student teachers as learning resource material for student teaching.
\end{abstract}

Keywords: Content Validity and Utilization, OBE-Based Student Teaching.

\section{Introduction}

Student teaching is considered as the crucial part of the education curriculum [10-12]. It is the culminating phase of the pre-service education training in every Teacher Education Institution (TEI). Each student teacher has to produce authentic evidences of learning outcomes in line with the mandate of Outcome-Based Education (OBE).

OBE has an intuitive appeal that hooks people. Simply set the outcomes you expect students to achieve, then teach and reteach in as many different ways and for as long as it 
takes until everyone meets them. In its simplest form, the OBE process virtually guarantees every student an education [4].

Hence, after the exposure to theories and concepts on classroom teaching, it is imperative that education students be ushered to the real world of education through OBE practice teaching where they can see the actual situation and experience first-hand the reality of the profession they have chosen. Thus, it is the peak of students' learning where they are confronted with issues concerning teaching lessons, classroom management, instructional material development, relationships with peers, cooperating teachers, supervisors, etc.

But no matter how much these students are equipped with the knowledge and skills for such training, if they are not aware of the foundation of the Student Teaching Program, Instructional Process they have to experience, the exact role they have to play as student teachers in dealing with the students, administrators, supervisors and cooperating teachers, they will. Hence, there is a need for a manual of guidelines and policies for a student teaching program. However, it should bear the authenticity of sound policies and guidelines. It should be validated before it is distributed and utilized.

This Student Teaching Manual (STM) is an offshoot of the dissertation of the researcher and modified to incorporate OBE-based activities to respond to the direction of the Commission of Higher Education (CHED) based on its Handbook on Typology, Outcomes-Based Education (OBE) and Institutional Quality System as published in 2014. The manual incorporated OBE approach that focuses and organizes the instructional system around what is essential for all student teachers to know, value, and be able to do to achieve a desired level of competence in their student teaching program using the "ADDIE" Instructional Design Model.

To make this OBE material useful in the student teaching program, it needs to be validated in its content and utilization.

This study aims to validate the content and assess utilization of an OBE-Based Student Teaching Manual. Specifically, this study will seek to answer the following questions: First, what is the content validity of the OBE-Based Student Teaching Manual in all its parts: Foundations of the Student Teaching Program (STP); Administration and Supervision in Student Teaching; Policies and Guidelines in Student Teaching; Instructional Activities in Student Teaching; and Methods of Assessment in Student Teaching. Secondly, how is the utilization of the OBE-Based Student Teaching Manual in the following instructional activities: Orientation Phase, Induction Phase; Assimilation Phase; and Integration Phase? Third, is there significant difference on the assessment of respondents in relation to the following: Content Validity of the OBE-Based Student Teaching Manual and Utilization of the OBE-Based Student Teaching Manual?

The outcome of the study will be beneficial to the stakeholders of the Student Teaching Program. The supervisors will utilize the manual to guide them in the different phases of the student teaching that would hasten the internship process that meets optimum students' learning. Likewise, the cooperating teachers will use the manual to guide them in mentoring the student teachers. This a practical resource material for student teachers and would have a better and deeper understanding of the essentials of student teaching.

This study on the content validation and utilization of OBE-Based Student Teaching Manual was conducted for persons involved in the student teaching program at ESSU 
College of Education-Main Campus for school year 2016-2017: Student Teachers, Cooperating Teachers, and Student Teaching Supervisors.

\section{Materials and Methods}

The study used a descriptive-evaluation research design as this involved assessing and describing the content validity and utilization of the OBE-Based Student Teaching Manual and was conducted at the College of Education-Main Campus of Eastern Samar State University (ESSU) and in selected cooperating schools where the student teachers and cooperating teachers are assigned/stationed for the second semester, school year 20162017. The main respondents were composed of the $30 \%$ of the total number of student teachers from the BEED and BSED programs who were randomly selected. Ten (10) cooperating teachers from different cooperating schools and the faculty members who have supervised the student teachers for the last three (3) years. These respondents were considered as panel of experts as they are made to assess for content validity and utilization of the prepared manual.

There were instruments was used in gathering the data of this study: Part One is a questionnaire was used to validate the OBE-Based Student Teaching Manual for the content on its five (5) parts: For content validity, the following five-point graduated scale was used by experts to rate the five parts in the OBE-Based manual for student teaching.

\begin{tabular}{ccl}
\hline Weighted score & Ranges & Qualitative description \\
\hline 5 & $4.50-5.00$ & Strongly agree \\
4 & $3.50-4.49$ & Agree \\
3 & $2.50-3.49$ & Moderately agree \\
2 & $1.50-2.49$ & Disagree \\
1 & $1.00-1.49$ & Strongly disagree \\
\hline
\end{tabular}

Part Two instrument was for the utilization of the manual, a score card was used to rate its usefulness along the different phases in the student teaching program:

The following five-point graduated scale was used to rate the proposed manual for student teaching in terms of its utilization:

\begin{tabular}{ccl}
\hline Weighted score & Ranges & Qualitative description \\
\hline 5 & $4.50-5.00$ & Strongly agree \\
4 & $3.50-4.49$ & Agree \\
3 & $2.50-3.49$ & Moderately agree \\
2 & $1.50-2.49$ & Disagree \\
1 & $1.00-1.49$ & Strongly disagree \\
\hline
\end{tabular}

The study was conducted towards the end of the second semester, school year 20162017 when the student teaching has ended with the four (4) instructional phases namely: orientation, induction, assimilation, and integration.

As the sample Student Teaching Manual had been distributed to the student teachers at the onset of their deployment for its "pre- trial" utilization, the distribution and retrieval of the questionnaire will be done personally by the researcher at the end of the student 
teaching experience of student teachers. The data collected from the research instruments were carefully tallied, analyzed, studied, and interpreted accordingly.

The data gathered were analyzed using the means, the weighted mean score, and the test of ANOVA, which will be tested at 0.05 level of significance.

\section{Results and Discussion}

\subsection{Content Validity of Student Teaching Manual}

Part one of the Student Teaching Manual (STM) is on the foundation of student teaching which the content was validated by the three groups of respondents: student teachers rated 4.72 (Strongly Agree), cooperating teachers rated 4.6 (Strongly Agree), and student teaching supervisors rated 4.82 (Strongly Agree) with a grand mean of 4.7 (Strongly Agree).

It is worth noting that, as indicated in Table 1, the three groups of respondents had expressed that the content on Foundation of Student teaching is valid as it reflects the necessary and relevant inputs needed to understand the objectives and rationale of the Student Teaching Program.

TABLE 1. Content validity on foundations of student teaching

\begin{tabular}{|c|c|c|c|c|c|}
\hline \multirow[b]{2}{*}{ Indicators } & \multicolumn{3}{|c|}{ Mean } & \multirow{2}{*}{$\begin{array}{l}\text { Average } \\
\text { mean }\end{array}$} & \multirow[b]{2}{*}{ Description } \\
\hline & $\begin{array}{l}\text { Student } \\
\text { teacher }\end{array}$ & $\begin{array}{c}\text { Cooperating } \\
\text { teacher }\end{array}$ & $\begin{array}{c}\text { ST } \\
\text { supervisor }\end{array}$ & & \\
\hline $\begin{array}{l}\text { The content is accurately } \\
\text { written. }\end{array}$ & 4.7 & 4.6 & 4.4 & 4.6 & $\begin{array}{l}\text { Strongly } \\
\text { agree }\end{array}$ \\
\hline $\begin{array}{l}\text { The content is clearly } \\
\text { presented. }\end{array}$ & 4.7 & 4.6 & 4.6 & 4.6 & $\begin{array}{l}\text { Strongly } \\
\text { agree }\end{array}$ \\
\hline $\begin{array}{l}\text { The content is relevant to } \\
\text { the course. }\end{array}$ & 4.9 & 4.7 & 5.0 & 4.8 & $\begin{array}{l}\text { Strongly } \\
\text { agree }\end{array}$ \\
\hline $\begin{array}{l}\text { The content is completely } \\
\text { provided. }\end{array}$ & 4.6 & 4.7 & 4.8 & 4.6 & $\begin{array}{l}\text { Strongly } \\
\text { agree }\end{array}$ \\
\hline $\begin{array}{l}\text { The content is significant } \\
\text { to the course. }\end{array}$ & 4.9 & 4.8 & 5.0 & 4.9 & $\begin{array}{l}\text { Strongly } \\
\text { agree }\end{array}$ \\
\hline $\begin{array}{l}\text { The content supports } \\
\text { the Teacher Education } \\
\text { Curriculum. }\end{array}$ & 4.8 & 4.8 & 5.0 & 4.9 & $\begin{array}{l}\text { Strongly } \\
\text { agree }\end{array}$ \\
\hline $\begin{array}{l}\text { The content is appropriate } \\
\text { to the needs of the user. }\end{array}$ & 4.6 & 4.6 & 5.0 & 4.7 & $\begin{array}{l}\text { Strongly } \\
\text { agree }\end{array}$ \\
\hline $\begin{array}{l}\text { The content considers the } \\
\text { individual differences of } \\
\text { users. }\end{array}$ & 4.4 & 4.4 & 4.8 & 4.5 & $\begin{array}{l}\text { Strongly } \\
\text { agree }\end{array}$ \\
\hline $\begin{array}{l}\text { The content captures users' } \\
\text { interest in the course. }\end{array}$ & 4.8 & 4.3 & 4.6 & 4.6 & $\begin{array}{l}\text { Strongly } \\
\text { agree }\end{array}$ \\
\hline $\begin{array}{l}\text { The content integrates the } \\
\text { real world of teaching. }\end{array}$ & 4.8 & 4.5 & 5.0 & 4,8 & $\begin{array}{l}\text { Strongly } \\
\text { agree }\end{array}$ \\
\hline Grand mean & 4.72 & 4.6 & 4.82 & 4.7 & $\begin{array}{l}\text { Strongly } \\
\text { agree }\end{array}$ \\
\hline
\end{tabular}


The second part of the STM is on Administration and Supervision of Student Teaching. The validators assessed its validity with a grand mean of 4.75 (Strongly Agree). ST Supervisors provided the highest rating (4.84) for content validity followed by student teachers (4.74) and cooperating teachers (4.67).

The item with the highest mean (4.9) which the validators strongly agree with is on relevancy of content of this part to the course on Student Teaching but the item on how the content captures the interest of the users is rated the lowest (4.61).

The findings imply that the content on Administration and Supervision of Student Teaching is valid. Despite of what is revealed in Table 2 that the respondents had strongly agreed that it captures students' interest, but this can still be improved in terms of its presentation to be more interesting to the users.

Contained in Part three of the STM is the Policies and Guidelines in Student Teaching. As reflected in Table 3, the overall mean rating of the three groups of respondents is 4.78 (Strongly Agree). The ST supervisors rated the highest with a mean score of 4.8 (Strongly Agree), Cooperating Teacher, 4.77 (Strongly Agree) and 4.75 (Strongly Agree) for the student teachers.

TABLE 2. Content validity on administration and supervision of student teaching

\begin{tabular}{|c|c|c|c|c|c|}
\hline \multirow[b]{2}{*}{ Indicators } & \multicolumn{3}{|c|}{ Mean } & \multirow{2}{*}{$\begin{array}{l}\text { Average } \\
\text { mean }\end{array}$} & \multirow[b]{2}{*}{ Description } \\
\hline & $\begin{array}{l}\text { Student } \\
\text { teacher }\end{array}$ & $\begin{array}{c}\text { Cooperating } \\
\text { teacher }\end{array}$ & $\begin{array}{c}\text { ST } \\
\text { supervisor }\end{array}$ & & \\
\hline $\begin{array}{l}\text { The content is accurately } \\
\text { written. }\end{array}$ & 4.72 & 4.8 & 4.4 & 4.64 & $\begin{array}{l}\text { Strongly } \\
\text { agree }\end{array}$ \\
\hline $\begin{array}{l}\text { The content is clearly } \\
\text { presented. }\end{array}$ & 4.79 & 4.8 & 4.6 & 4.73 & $\begin{array}{l}\text { Strongly } \\
\text { agree }\end{array}$ \\
\hline $\begin{array}{l}\text { The content is relevant to } \\
\text { the course. }\end{array}$ & 4.80 & 4.9 & 5.0 & 4.9 & $\begin{array}{l}\text { Strongly } \\
\text { agree }\end{array}$ \\
\hline $\begin{array}{l}\text { The content is completely } \\
\text { provided. }\end{array}$ & 4.73 & 4.5 & 4.8 & 4.68 & $\begin{array}{l}\text { Strongly } \\
\text { agree }\end{array}$ \\
\hline $\begin{array}{l}\text { The content is significant } \\
\text { to the course. }\end{array}$ & 4.88 & 4.8 & 5.0 & 4.89 & $\begin{array}{l}\text { Strongly } \\
\text { agree }\end{array}$ \\
\hline $\begin{array}{l}\text { The content supports } \\
\text { the Teacher Education } \\
\text { Curriculum. }\end{array}$ & 4.86 & 4.8 & 5.0 & 4.89 & $\begin{array}{l}\text { Strongly } \\
\text { agree }\end{array}$ \\
\hline $\begin{array}{l}\text { The content is appropriate } \\
\text { to the needs of the user. }\end{array}$ & 4.68 & 4.6 & 5.0 & 4.76 & $\begin{array}{l}\text { Strongly } \\
\text { agree }\end{array}$ \\
\hline $\begin{array}{l}\text { The content considers the } \\
\text { individual differences of } \\
\text { users. }\end{array}$ & 4.58 & 4.5 & 4.8 & 4.63 & $\begin{array}{l}\text { Strongly } \\
\text { agree }\end{array}$ \\
\hline $\begin{array}{l}\text { The content captures } \\
\text { users' interest in the } \\
\text { course. }\end{array}$ & 4.62 & 4.4 & 4.8 & 4.61 & $\begin{array}{l}\text { Strongly } \\
\text { agree }\end{array}$ \\
\hline $\begin{array}{l}\text { The content integrates the } \\
\text { real world of teaching. }\end{array}$ & 4.7 & 4.6 & 5.0 & 4.77 & $\begin{array}{l}\text { Strongly } \\
\text { agree }\end{array}$ \\
\hline Grand Mean & 4.74 & 4.67 & 4.84 & 4.75 & $\begin{array}{l}\text { Strongly } \\
\text { agree }\end{array}$ \\
\hline
\end{tabular}


Validating and Utilizing an Outcomes-Based Education (OBE) Student Teaching Manual in a State University in the Philippines

TABLE 3. Content validity on policies and guidelines in student teaching

\begin{tabular}{|c|c|c|c|c|c|}
\hline \multirow[b]{2}{*}{ Indicators } & \multicolumn{3}{|c|}{ Mean } & \multirow[b]{2}{*}{$\begin{array}{l}\text { Average } \\
\text { mean }\end{array}$} & \multirow[b]{2}{*}{ Description } \\
\hline & $\begin{array}{l}\text { Student } \\
\text { teacher }\end{array}$ & $\begin{array}{l}\text { Cooperating } \\
\text { teacher }\end{array}$ & $\begin{array}{c}\text { ST } \\
\text { Supervisor }\end{array}$ & & \\
\hline $\begin{array}{l}\text { The content is accurately } \\
\text { written. }\end{array}$ & 4.88 & 4.9 & 4.4 & 4.73 & $\begin{array}{l}\text { Strongly } \\
\text { agree }\end{array}$ \\
\hline $\begin{array}{l}\text { The content is clearly } \\
\text { presented. }\end{array}$ & 4.83 & 4.7 & 4.4 & 4.64 & $\begin{array}{l}\text { Strongly } \\
\text { agree }\end{array}$ \\
\hline $\begin{array}{l}\text { The content is relevant to } \\
\text { the course. }\end{array}$ & 4.92 & 4.9 & 5.0 & 4.94 & $\begin{array}{l}\text { Strongly } \\
\text { agree }\end{array}$ \\
\hline $\begin{array}{l}\text { The content is completely } \\
\text { provided. }\end{array}$ & 4.71 & 4.8 & 4.8 & 4.77 & $\begin{array}{l}\text { Strongly } \\
\text { agree }\end{array}$ \\
\hline $\begin{array}{l}\text { The content is significant } \\
\text { to the course. }\end{array}$ & 4.92 & 4.8 & 5.0 & 4.91 & $\begin{array}{l}\text { Strongly } \\
\text { agree }\end{array}$ \\
\hline $\begin{array}{l}\text { The content supports } \\
\text { the Teacher Education } \\
\text { Curriculum. }\end{array}$ & 4.83 & 4.8 & 5.0 & 4.88 & $\begin{array}{l}\text { Strongly } \\
\text { agree }\end{array}$ \\
\hline $\begin{array}{l}\text { The content is appropriate } \\
\text { to the needs of the user. }\end{array}$ & 4.73 & 4.8 & 5.0 & 4.84 & $\begin{array}{l}\text { Strongly } \\
\text { agree }\end{array}$ \\
\hline $\begin{array}{l}\text { The content considers the } \\
\text { individual differences of } \\
\text { users. }\end{array}$ & 4.68 & 4.6 & 4.8 & 4.69 & $\begin{array}{l}\text { Strongly } \\
\text { agree }\end{array}$ \\
\hline $\begin{array}{l}\text { The content captures } \\
\text { users' interest in the } \\
\text { course. }\end{array}$ & 4.35 & 4.7 & 4.6 & 4.55 & $\begin{array}{l}\text { Strongly } \\
\text { agree }\end{array}$ \\
\hline $\begin{array}{l}\text { The content integrates the } \\
\text { real world of teaching. }\end{array}$ & 4.76 & 4.7 & 5.0 & 4.82 & $\begin{array}{l}\text { Strongly } \\
\text { agree }\end{array}$ \\
\hline Grand mean & 4.76 & 4.77 & 4.8 & 4.78 & $\begin{array}{l}\text { Strongly } \\
\text { agree }\end{array}$ \\
\hline
\end{tabular}

All items are validated with very strong agreement on all conditions on content validity for this particular part of STM. The highest mean rating (4.94) on the relevancy of the content to the course and lowest rating (4.55), the content captivates user's interest.

The data imply the content in Part III, Policies and Guidelines in Student Teaching is valid. However, it is wanting to improve on its content that would match the interest of the users.

Part four of the STM is on Instructional Activities in Student Teaching. As reflected in Table 4, the validators rated the content of this part: ST Supervisor and Student Teachers have the same rating (4.8) and Cooperating Teachers (4.54). The grand mean is 4.72 (Strongly Agree).

It is worthy to note that the content of this part is relevant as it gets the highest mean (4.84). However, the lowest mean score (4.59) is on the clarity of the presentation of content.

These data signifies that the content of Part IV of the STM on Instructional Activities in Student Teaching is valid. However, the data suggest that there is a need to improve the presentation of the Instructional Activities for the student teachers to undertake the 
TABLE 4. Content validity on instructional activities in student teaching

\begin{tabular}{|c|c|c|c|c|c|}
\hline \multirow[b]{2}{*}{ Indicators } & \multicolumn{3}{|c|}{ Mean } & \multirow{2}{*}{$\begin{array}{c}\text { Average } \\
\text { mean }\end{array}$} & \multirow[b]{2}{*}{ Description } \\
\hline & $\begin{array}{l}\text { Student } \\
\text { teacher }\end{array}$ & $\begin{array}{c}\text { Cooperating } \\
\text { teacher }\end{array}$ & $\begin{array}{c}\text { ST } \\
\text { supervisor }\end{array}$ & & \\
\hline $\begin{array}{l}\text { The content is accurately } \\
\text { written. }\end{array}$ & 5.0 & 4.6 & 4.4 & 4.67 & $\begin{array}{l}\text { Strongly } \\
\text { agree }\end{array}$ \\
\hline $\begin{array}{l}\text { The content is clearly } \\
\text { presented. }\end{array}$ & 4.77 & 4.6 & 4.4 & 4.59 & $\begin{array}{l}\text { Strongly } \\
\text { agree }\end{array}$ \\
\hline $\begin{array}{l}\text { The content is relevant to } \\
\text { the course. }\end{array}$ & 4.91 & 4.6 & 5.0 & 4.84 & $\begin{array}{l}\text { Strongly } \\
\text { agree }\end{array}$ \\
\hline $\begin{array}{l}\text { The content is completely } \\
\text { provided. }\end{array}$ & 4.62 & 4.6 & 4.8 & 4.67 & $\begin{array}{l}\text { Strongly } \\
\text { agree }\end{array}$ \\
\hline $\begin{array}{l}\text { The content is significant } \\
\text { to the course. }\end{array}$ & 4.86 & 4.6 & 5.0 & 4.82 & $\begin{array}{l}\text { Strongly } \\
\text { agree }\end{array}$ \\
\hline $\begin{array}{l}\text { The content supports } \\
\text { the Teacher Education } \\
\text { Curriculum. }\end{array}$ & 4.83 & 4.5 & 5.0 & 4.78 & $\begin{array}{l}\text { Strongly } \\
\text { agree }\end{array}$ \\
\hline $\begin{array}{l}\text { The content is appropriate } \\
\text { to the needs of the user. }\end{array}$ & 4.8 & 4.5 & 5.0 & 4.77 & $\begin{array}{l}\text { Strongly } \\
\text { agree }\end{array}$ \\
\hline $\begin{array}{l}\text { The content considers the } \\
\text { individual differences of } \\
\text { users. }\end{array}$ & 4.73 & 4.4 & 4.8 & 4.64 & $\begin{array}{l}\text { Strongly } \\
\text { agree }\end{array}$ \\
\hline $\begin{array}{l}\text { The content captures } \\
\text { users' interest in the } \\
\text { course. }\end{array}$ & 4.77 & 4.5 & 4.6 & 4.62 & $\begin{array}{l}\text { Strongly } \\
\text { agree }\end{array}$ \\
\hline $\begin{array}{l}\text { The content integrates the } \\
\text { real world of teaching. }\end{array}$ & 4.88 & 4.5 & 5.0 & 4.79 & $\begin{array}{l}\text { Strongly } \\
\text { agree }\end{array}$ \\
\hline Grand mean & 4.82 & 4.54 & 4.8 & 4.72 & $\begin{array}{l}\text { Strongly } \\
\text { agree }\end{array}$ \\
\hline
\end{tabular}

activities properly and answer the questions accurately. Hence, the respondents imply to redesign the content for a clearer presentation.

Methods of Assessment in Student Teaching is the fifth and last part of the STM. For Its content validity as depicted in Table 5. The grand mean is 4.76 (Strongly Agree). The ST supervisors rated 4.84 (Strongly Agree), Student Teachers, 4.81 (Strongly Agree) and Cooperating Teachers 4.64 (Very Strong).

TABLE 5. Content validity on methods of assessment in student teaching

\begin{tabular}{|c|c|c|c|c|c|}
\hline \multirow[b]{2}{*}{ Indicators } & \multicolumn{3}{|c|}{ Mean } & \multirow{2}{*}{$\begin{array}{l}\text { Average } \\
\text { mean }\end{array}$} & \multirow[b]{2}{*}{ Description } \\
\hline & $\begin{array}{l}\text { Student } \\
\text { teacher }\end{array}$ & $\begin{array}{c}\text { Cooperating } \\
\text { teacher }\end{array}$ & $\begin{array}{c}\text { ST } \\
\text { supervisor }\end{array}$ & & \\
\hline $\begin{array}{l}\text { The content is accurately } \\
\text { written. }\end{array}$ & 4.82 & 4.6 & 4.4 & 4.61 & $\begin{array}{l}\text { Strongly } \\
\text { agree }\end{array}$ \\
\hline $\begin{array}{l}\text { The content is clearly } \\
\text { presented. }\end{array}$ & 4.80 & 4.6 & 4.6 & 4.67 & $\begin{array}{l}\text { Strongly } \\
\text { agree }\end{array}$ \\
\hline $\begin{array}{l}\text { The content is relevant to } \\
\text { the course. }\end{array}$ & 4.91 & 4.8 & 5.0 & 4.9 & $\begin{array}{l}\text { Strongly } \\
\text { agree }\end{array}$ \\
\hline $\begin{array}{l}\text { The content is completely } \\
\text { provided. }\end{array}$ & 4.80 & 4.6 & 4.8 & 4.73 & $\begin{array}{l}\text { Strongly } \\
\text { agree }\end{array}$ \\
\hline
\end{tabular}


Validating and Utilizing an Outcomes-Based Education (OBE) Student Teaching Manual in a State University in the Philippines

\begin{tabular}{|c|c|c|c|c|c|}
\hline $\begin{array}{l}\text { The content is significant } \\
\text { to the course. }\end{array}$ & 4.85 & 4.9 & 5.0 & 4.92 & $\begin{array}{l}\text { Strongly } \\
\text { agree }\end{array}$ \\
\hline $\begin{array}{l}\text { The content supports } \\
\text { the Teacher Education } \\
\text { Curriculum. }\end{array}$ & 4.86 & 4.7 & 5.0 & 4.85 & $\begin{array}{l}\text { Strongly } \\
\text { agree }\end{array}$ \\
\hline $\begin{array}{l}\text { The content is appropriate } \\
\text { to the needs of the user. }\end{array}$ & 4.83 & 4.6 & 5.0 & 4.81 & $\begin{array}{l}\text { Strongly } \\
\text { agree }\end{array}$ \\
\hline $\begin{array}{l}\text { The content considers the } \\
\text { individual differences of } \\
\text { users. }\end{array}$ & 4.71 & 4.5 & 4.8 & 4.67 & $\begin{array}{l}\text { Strongly } \\
\text { agree }\end{array}$ \\
\hline $\begin{array}{l}\text { The content captures } \\
\text { users' interest in the } \\
\text { course. }\end{array}$ & 4.74 & 4.5 & 4.8 & 4.68 & $\begin{array}{l}\text { Strongly } \\
\text { agree }\end{array}$ \\
\hline $\begin{array}{l}\text { The content integrates the } \\
\text { real world of teaching. }\end{array}$ & 4.77 & 4.6 & 5.0 & 4.79 & $\begin{array}{l}\text { Strongly } \\
\text { agree }\end{array}$ \\
\hline Grand mean & 4.81 & 4.64 & 4.84 & 4.76 & $\begin{array}{l}\text { Strongly } \\
\text { agree }\end{array}$ \\
\hline
\end{tabular}

The highest mean (4.92) is on the statement that the content of Part V is significant which means that the users themselves have expressed that the inputs are of great importance on understanding how the student's performance will be assessed and how the Cooperating Teachers and ST Supervisors will assess the student teaching performance.

\section{Utilization of the OBE-Based Student Teaching Manual}

Table 6 indicates the assessment of the three groups of respondents on the utilization of Student Teaching Manual in the Orientation Phase. The highest mean 4.73 (Strongly Agree) was on the practical use of the manual during the entire period of student teaching,

TABLE 6. Utilization of student teaching manual in the orientation phase

\begin{tabular}{|c|c|c|c|c|c|}
\hline \multirow[b]{2}{*}{ Indicators } & \multicolumn{3}{|c|}{ Mean } & \multirow{2}{*}{$\begin{array}{l}\text { Average } \\
\text { mean }\end{array}$} & \multirow[b]{2}{*}{ Description } \\
\hline & $\begin{array}{l}\text { Student } \\
\text { teacher }\end{array}$ & $\begin{array}{c}\text { Cooperating } \\
\text { teacher }\end{array}$ & $\begin{array}{c}\text { ST } \\
\text { supervisor }\end{array}$ & & \\
\hline $\begin{array}{l}\text { The manual is utilized } \\
\text { easily. }\end{array}$ & 4.65 & 4.5 & 4.6 & 4.58 & $\begin{array}{l}\text { Strongly } \\
\text { agree }\end{array}$ \\
\hline $\begin{array}{l}\text { The manual is utilized } \\
\text { practically. }\end{array}$ & 4.7 & 4.5 & 5.0 & 4.73 & $\begin{array}{l}\text { Strongly } \\
\text { agree }\end{array}$ \\
\hline $\begin{array}{l}\text { The manual is utilized } \\
\text { regularly. }\end{array}$ & 4.45 & 4.3 & 4.6 & 4.45 & Agree \\
\hline $\begin{array}{l}\text { The manual is utilized } \\
\text { interestingly. }\end{array}$ & 4.47 & 4.4 & 4.8 & 4.56 & $\begin{array}{l}\text { Strongly } \\
\text { agree }\end{array}$ \\
\hline $\begin{array}{l}\text { The manual is utilized } \\
\text { fully. }\end{array}$ & 4.58 & 4.4 & 4.6 & 4.53 & $\begin{array}{l}\text { Strongly } \\
\text { agree }\end{array}$ \\
\hline Grand mean & 4.57 & 4.42 & 4.72 & 4.57 & $\begin{array}{l}\text { Strongly } \\
\text { agree }\end{array}$ \\
\hline
\end{tabular}


second highest mean in the list was the STM is utilized easily, 4.58 (Strongly Agree), and the third highest was on the manual is utilized interestingly 4.56 (Strongly Agree).

Interestingly, the highest grand mean 4.72 (Strongly Agree) was obtained from the group of supervisors. This would implicate that the use of STM as a resource material during the orientation phase facilitated them in orienting the student teachers on the Foundations of Student Teaching, Administration and Supervision, Policies and Guidelines, Instructional Activities and Methods of Assessment.

It is worthy to note that the grand mean is 4.57 that indicates a very high agreement that the STM is utilized easily, practically, regularly, interestingly, and fully in the Orientation Phase in their Student Teaching. This implies further that at the time the student teachers and supervisors were having an orientation on student teaching, STM was very useful.

Reflected in Table 7 are the mean scores obtained from the three groups of respondents in terms of their assessment on the utilization of STM during the Induction Phase. It is revealed that on the practical usage of the STM got the highest mean, 4.79 (Strongly Agree), followed by respondents' strong agreement (4.73) on the easy use of the STM and agreed on interesting use of the STM during the Induction Phase (4.66).

Student Teaching Supervisors rated the highest (4.8, Strongly Agree) among the three groups of respondents, followed by the student teachers (4.69, Strongly Agree) and cooperating teachers (4.52, Strongly Agree) (which implies that utilization of STM per se during the Induction Phase of Student Teachers was really of great use as it hastened their work in the accomplishment of instructional activities in student teaching).

Table 8 indicates the assessment of the three groups of respondents on the utilization of Student Teaching Manual in the Assimilation Phase. The highest mean 4.77 (Strongly Agree) was on the practical use of the manual during the entire period of student teaching, second highest mean in the list was the STM is utilized fully, 4.75 (Strongly Agree), and the third highest was on the manual is utilized interestingly 4.68 (Strongly Agree).

Interestingly, the highest grand mean 4.8 (Strongly Agree) was obtained from the group of supervisors. This would imply that the use of STM as a resource material during the

TABLE 7. Utilization of student teaching manual in the induction phase

\begin{tabular}{|c|c|c|c|c|c|}
\hline \multirow[b]{2}{*}{ Indicators } & \multicolumn{3}{|c|}{ Mean } & \multirow{2}{*}{$\begin{array}{l}\text { Average } \\
\text { mean }\end{array}$} & \multirow[b]{2}{*}{ Description } \\
\hline & $\begin{array}{l}\text { Student } \\
\text { teacher }\end{array}$ & $\begin{array}{c}\text { Cooperating } \\
\text { teacher }\end{array}$ & $\begin{array}{c}\text { ST } \\
\text { supervisor }\end{array}$ & & \\
\hline $\begin{array}{l}\text { The manual is utilized } \\
\text { easily. }\end{array}$ & 4.68 & 4.7 & 4.8 & 4.73 & $\begin{array}{l}\text { Strongly } \\
\text { agree }\end{array}$ \\
\hline $\begin{array}{l}\text { The manual is utilized } \\
\text { practically. }\end{array}$ & 4.76 & 4.6 & 5.0 & 4.79 & $\begin{array}{l}\text { Strongly } \\
\text { agree }\end{array}$ \\
\hline $\begin{array}{l}\text { The manual is utilized } \\
\text { regularly. }\end{array}$ & 4.59 & 4.4 & 4.6 & 4.53 & $\begin{array}{l}\text { Strongly } \\
\text { agree }\end{array}$ \\
\hline $\begin{array}{l}\text { The manual is utilized } \\
\text { interestingly. }\end{array}$ & 4.67 & 4.5 & 4.8 & 4.66 & $\begin{array}{l}\text { Strongly } \\
\text { agree }\end{array}$ \\
\hline $\begin{array}{l}\text { The manual is utilized } \\
\text { fully. }\end{array}$ & 4.76 & 4.4 & 4.8 & 4.65 & $\begin{array}{l}\text { Strongly } \\
\text { agree }\end{array}$ \\
\hline Grand mean & 4.69 & 4.52 & 4.8 & 4.67 & $\begin{array}{l}\text { Strongly } \\
\text { agree }\end{array}$ \\
\hline
\end{tabular}


Validating and Utilizing an Outcomes-Based Education (OBE) Student Teaching Manual in a State University in the Philippines

TABLE 8. Utilization of student teaching manual in the assimilation phase

\begin{tabular}{|c|c|c|c|c|c|}
\hline \multirow[b]{2}{*}{ Indicators } & \multicolumn{3}{|c|}{ Mean } & \multirow{2}{*}{$\begin{array}{l}\text { Average } \\
\text { mean }\end{array}$} & \multirow[b]{2}{*}{ Description } \\
\hline & $\begin{array}{l}\text { Student } \\
\text { teacher }\end{array}$ & $\begin{array}{l}\text { Cooperating } \\
\text { teacher }\end{array}$ & $\begin{array}{c}\text { ST } \\
\text { Supervisor }\end{array}$ & & \\
\hline $\begin{array}{l}\text { The manual is utilized } \\
\text { easily. }\end{array}$ & 4.51 & 4.7 & 4.8 & 4.67 & $\begin{array}{l}\text { Strongly } \\
\text { agree }\end{array}$ \\
\hline $\begin{array}{l}\text { The manual is utilized } \\
\text { practically. }\end{array}$ & 4.81 & 4.5 & 5.0 & 4.77 & $\begin{array}{l}\text { Strongly } \\
\text { agree }\end{array}$ \\
\hline $\begin{array}{l}\text { The manual is utilized } \\
\text { regularly. }\end{array}$ & 4.7 & 4.3 & 4.6 & 4.53 & $\begin{array}{l}\text { Strongly } \\
\text { agree }\end{array}$ \\
\hline $\begin{array}{l}\text { The manual is utilized } \\
\text { interestingly. }\end{array}$ & 4.74 & 4.5 & 4.8 & 4.68 & $\begin{array}{l}\text { Strongly } \\
\text { agree }\end{array}$ \\
\hline $\begin{array}{l}\text { The manual is utilized } \\
\text { fully. }\end{array}$ & 4.86 & 4.6 & 4.8 & 4.75 & $\begin{array}{l}\text { Strongly } \\
\text { agree }\end{array}$ \\
\hline Grand mean & 4.72 & 4.52 & 4.8 & 4.68 & $\begin{array}{l}\text { Strongly } \\
\text { agree }\end{array}$ \\
\hline
\end{tabular}

assimilation phase facilitated them in the exposure of the student teachers on the daily teaching activities, straight teaching, demonstration teaching, and conferences.

It is worthy to note that the grand average mean is 4.68 , indicates a very high agreement among the three groups of respondents.

It indicated that the STM is utilized easily, practically, regularly, interestingly, and fully in the Assimilation Phase in their Student Teaching. This implies further that the time the student teachers and supervisors were having actual hands-on experiences in the Student Teaching Program, STM was very useful.

Reflected in Table 9 are the mean scores obtained from the three groups of respondents in terms of their assessment on the utilization of STM during the Integration Phase. It is revealed that on the practical usage of the STM got the highest mean, 4.84 (Strongly

TABLE 9. Utilization of student teaching manual in the integration phase

\begin{tabular}{|c|c|c|c|c|c|}
\hline \multirow[b]{2}{*}{ Indicators } & \multicolumn{3}{|c|}{ Mean } & \multirow{2}{*}{$\begin{array}{l}\text { Average } \\
\text { mean }\end{array}$} & \multirow[b]{2}{*}{ Description } \\
\hline & $\begin{array}{l}\text { Student } \\
\text { teacher }\end{array}$ & $\begin{array}{l}\text { Cooperat- } \\
\text { ing teacher }\end{array}$ & $\begin{array}{c}\text { ST } \\
\text { supervisor }\end{array}$ & & \\
\hline $\begin{array}{l}\text { The manual is utilized } \\
\text { easily. }\end{array}$ & 4.80 & 4.6 & 4.8 & 4.73 & $\begin{array}{l}\text { Strongly } \\
\text { agree }\end{array}$ \\
\hline $\begin{array}{l}\text { The manual is utilized } \\
\text { practically. }\end{array}$ & 4.81 & 4.7 & 5.0 & 4.84 & $\begin{array}{l}\text { Strongly } \\
\text { agree }\end{array}$ \\
\hline $\begin{array}{l}\text { The manual is utilized } \\
\text { regularly. }\end{array}$ & 4.64 & 4.6 & 4.8 & 4.68 & $\begin{array}{l}\text { Strongly } \\
\text { agree }\end{array}$ \\
\hline $\begin{array}{l}\text { The manual is utilized } \\
\text { interestingly. }\end{array}$ & 4.77 & 4.4 & 4.8 & 4.66 & $\begin{array}{l}\text { Strongly } \\
\text { agree }\end{array}$ \\
\hline $\begin{array}{l}\text { The manual is utilized } \\
\text { fully. }\end{array}$ & 4.86 & 4.4 & 4.8 & 4.69 & $\begin{array}{l}\text { Strongly } \\
\text { agree }\end{array}$ \\
\hline Grand mean & 4.78 & 4.54 & 4.84 & 4.72 & $\begin{array}{l}\text { Strongly } \\
\text { agree }\end{array}$ \\
\hline
\end{tabular}


Agree), followed by respondents' strong agreement (4.73) on the easy use of the STM and agreed on interesting use of the STM during the Integration Phase (4.66).

Student Teaching Supervisors rated the highest (4.84, Strongly Agree) among the three groups of respondents, followed by the student teachers (4.78, Strongly Agree) and cooperating teachers (4.54, Strongly Agree) which implies that utilization of STM per se during the Integration Phase of Student Teachers was really of great use to them as it was used as their guide in the accomplishment of all requirements in student teaching such as journal, portfolio, etc.

The overall grand average mean is 4.72 (Strongly Agree) reflects that the STM is utilized easily, practically, regularly, interestingly, and fully in the Integration Phase in their Student Teaching. This clearly implies that student teachers were using the STM to understand the requirements they have to accomplish and how they will be rated by the supervisors and cooperating teachers.

Table 10 shows the summary of the average mean scores of the three groups of respondents: student teachers, cooperating teachers, and ST supervisors on the content validation of STM. They all evaluated with strong agreement that the content of STM is valid.

Table 11 shows the summary of the average mean scores of the three groups of respondents: student teachers, cooperating teachers, and ST supervisors. They all expressed their strong agreement that the STM was utilized in the four (4) phases of the student teaching program.

As presented in Tables 12 and 13 respectively, there is a strong indication that the ratings among the three groups of respondents on the content validation in the five parts of the OBE-Student Teaching Manual are not significantly different. Furthermore, there was a notable revelation that there were no significant differences on the ratings provided by [9] the stakeholders: student teachers, cooperating teachers, and ST supervisors on the

TABLE 10. Summary table for the content validation STM by the three groups of respondents

\begin{tabular}{|c|c|c|c|c|c|}
\hline \multirow[t]{2}{*}{ Contents in the STM } & \multicolumn{4}{|c|}{$\begin{array}{l}\text { Average mean scores of the three groups of } \\
\text { respondents }\end{array}$} & \multirow[t]{2}{*}{ Description } \\
\hline & $\begin{array}{l}\text { Student } \\
\text { teachers }\end{array}$ & $\begin{array}{l}\text { Cooperating } \\
\text { teachers }\end{array}$ & $\begin{array}{c}\text { ST } \\
\text { supervisors }\end{array}$ & $\begin{array}{c}\text { Grand } \\
\text { average } \\
\text { mean }\end{array}$ & \\
\hline $\begin{array}{l}\text { Foundation of student } \\
\text { teaching }\end{array}$ & 4.72 & 4.6 & 4.82 & 4.7 & $\begin{array}{l}\text { Strongly } \\
\text { agree }\end{array}$ \\
\hline $\begin{array}{l}\text { Administration and } \\
\text { supervision }\end{array}$ & 4.74 & 4.67 & 4.84 & 4.75 & $\begin{array}{l}\text { Strongly } \\
\text { agree }\end{array}$ \\
\hline Policies and guidelines & 4.76 & 4.77 & 4.8 & 4.78 & $\begin{array}{l}\text { Strongly } \\
\text { agree }\end{array}$ \\
\hline Instructional activities & 4.86 & 4.54 & 4.8 & 4.72 & $\begin{array}{l}\text { Strongly } \\
\text { agree }\end{array}$ \\
\hline Assessment & 4.81 & 4.64 & 4.84 & 4.76 & $\begin{array}{l}\text { Strongly } \\
\text { agree }\end{array}$ \\
\hline
\end{tabular}


Validating and Utilizing an Outcomes-Based Education (OBE) Student Teaching Manual in a State University in the Philippines

TABLE 11. Summary table for the utilization of STM by the three groups of respondents

\begin{tabular}{|c|c|c|c|c|c|}
\hline \multirow[t]{2}{*}{$\begin{array}{l}\text { Phases in student } \\
\text { teaching }\end{array}$} & \multicolumn{4}{|c|}{$\begin{array}{l}\text { Average mean scores of the three groups of } \\
\text { respondents }\end{array}$} & \multirow[t]{2}{*}{ Description } \\
\hline & $\begin{array}{l}\text { Student } \\
\text { teachers }\end{array}$ & $\begin{array}{l}\text { Cooperating } \\
\text { teachers }\end{array}$ & $\begin{array}{c}\text { ST } \\
\text { supervisors }\end{array}$ & $\begin{array}{c}\text { Grand } \\
\text { average } \\
\text { mean }\end{array}$ & \\
\hline Orientation phase & 4.57 & 4.42 & 4.6 & 4.57 & $\begin{array}{l}\text { Strongly } \\
\text { agree }\end{array}$ \\
\hline Induction phase & 4.69 & 4.52 & 4.8 & 4.67 & $\begin{array}{l}\text { Strongly } \\
\text { agree }\end{array}$ \\
\hline Assimilation phase & 4.72 & 4.52 & 4.8 & 4.68 & $\begin{array}{l}\text { Strongly } \\
\text { agree }\end{array}$ \\
\hline Integration phase & 4.78 & 4.54 & 4.88 & 4.72 & $\begin{array}{l}\text { Strongly } \\
\text { agree }\end{array}$ \\
\hline
\end{tabular}

TABLE 12. Mean difference on the STM content validation between three groups of respondents

\begin{tabular}{lccc}
\hline Mean scores in content validation & $\boldsymbol{f}$ value & $\boldsymbol{p}$ value & Interpretation \\
\hline Student teachers & 0.33 & 0.667 & Not significant \\
Cooperating teachers & & & \\
ST supervisors & & & \\
\hline
\end{tabular}

0.05 level of significance.

TABLE 13. Mean difference on the STM utilization of three groups of respondents

\begin{tabular}{lccc}
\hline Mean scores in content validation & $\boldsymbol{f}$ value & $\boldsymbol{p}$ value & Interpretation \\
Student teachers & 0.33 & 0.667 & Not significant \\
$\begin{array}{l}\text { Cooperating teachers } \\
\text { ST supervisors }\end{array}$ & & & \\
\hline
\end{tabular}

0.05 level of significance.

Utilization of the OBE-Student Teaching Manual as the two $p$ values are greater than the significance level set at 0.05 .

\section{Conclusion}

The content of the OBE-Based Student Teaching Manual is valid as determined by the expert judgment of the student teachers, cooperating teachers, and student teaching supervisors of the Student Teaching Program. The content extensively fulfills the purpose for which it is used in terms of its Objectives of Student Teaching; Administration and Supervision, Instructional Activities, Policies; and Method of Assessment.

In the same manner, the manual was found out to be usable as evaluated by the stakeholders in the different phases of student teaching program in a Teacher Training Institution in the Philippines on the following phases: Orientation Phase; Induction Phase; Assimilation Phase; and Integration Phase. 
The three groups of evaluators have reached almost common judgment in relation to the content validity and utilization of the OBE-Based Student Teaching Manual. Hence, this manual is highly recommended to be used by student teachers as learning resource material in their student teaching internship as it had followed the OBE key principles as emphasized by which clearly defines outcomes, expands learning opportunities and sets high expectations for learning success among the student teachers.

\section{References}

1. Student teaching handbook. https:/www1.villanova.edu/content/villanova/artsci/education/ undergrad/secondaryed/_jcr_content/pagecontent/collapsecontent_575321773/par_ Student\%20Teaching\%20Handbook199/download/file.res/Student\%20Teaching\%20 Handbook\%202018-2019.pdf. Date accessed: 2000.

2. Supervising student teachers in a professional way. https://www.amazon.in/SupervisingStudent-Teachers-Professional-Way-ebook/dp/B009W3J066. Date accessed: 1989.

3. Principles of teaching (OBE and $\mathrm{K}$ to 12). https://chaymiclona.wixsite.com/grinimworju/singlepost/2018/03/30/Principles-Of-Teaching-1-By-Corpuz-And-Salandanan-Pdf. Date accessed: 2015.

4. The outcomes of outcome-based education: research and implications. file://C:/Users/a/ Downloads/7800103_1992_The\%20Outcomes\%20of\%20Outcome-Based\%20Education\%20 -\%20Research\%20and\%20Implications_Evans_final.pdf. Date accessed: 04/1992.

5. Developmental supervision: alternative practices for helping-teachers improve instruction. https://www.amazon.com/Developmental-Supervision-Alternative-Practices-Instruction/dp/ 0871201062. Date accessed: 01/06/1981.

6. Studentteaching and schoolexperiences.https://www.scirp.org/(S(351jmbntvnsjt1aadkposzje))/ reference/ReferencesPapers.aspx?ReferenceID=1185578. Date accessed: 1990.

7. Reganit AR, Osea, AP. Essential of student teaching. Mutya Publishing House: Valenzuela City. 2004.

8. Efficacy of ADDIE model in the digital classroom: an evidence based study. https://www. researchgate.net/publication/281711645_EFFICACY_OF_ADDIE_MODEL_IN_THE_ DIGITAL_CLASSROOM_AN_EVIDENCE_BASED_STUDY. Date accessed: 09/2015.

9. Unintended outcomes: curriculum and Outcome-Based Education. https://eric. ed.gov/?id=ED359205. Date accessed: 1993.

10. Making the difference for teachers field experience in actual practice. https://eric. ed.gov/?id=ED385511. Date accessed: 1995.

11. The field experience: creating successful programs for new teachers. http://movelovesun.com/ prokla_forem $2 /$ ?q=The+Field+Experience+Creating + Successful+Programs + For + New + Teach ers. Date accessed: 1995.

12. Preparing new teachers: operating successful field experience programs. https://eric. ed.gov/?id=ED385510. Date accessed: 1995.

13. A case study of professors' and instructional designers' experiences in the development of online courses. https://www.semanticscholar.org/paper/A-Case-Study-of-Professors'-andInstructional-in-of-Stevens/840cc0dafe218f481dbc9ed3f8927a96be155675. Date accessed: 2012.

14. The student teaching experience: cases from the classroom program. https://www.amazon. com/Student-Teaching-Experience-Cases-Classroom/dp/0130261009. Date accessed: 2001. 